\title{
Perception Theory on Reflective Teaching
}

\section{Sheila Mae M. Niones}

\author{
Bohol Is land State University - Clarin Campus \\ shel_sybe@yahoo.com
}

\begin{abstract}
Reflective teachers are effective teachers. With this notion, teachers have to practice reflective teaching inside their classes to emphasize that they are effective teachers. Since teachers' practices are not always expected to be reflective, this study discovered the junior high school English teachers' reflective teaching practices. It further investigated their reflective teaching practices through the help of their principals and students; teachers' accounts in their teaching practices were itemized. Using inductive approach on theory generation through quantitativequalitative research, the findings revealed the English teachers' level of reflection, their teaching practices, and their accounts on their teaching practices. Analysis of the responses also revealed the different themes in the English teachers' reflective teaching practices, thus the emergence of perception theory on reflective teaching. In-service English teachers need to undergo self-reflection to know more of themselves as teachers and to base modifications of classroom procedures. The school administration may conduct in-service training on reflective teaching practices since these in-service English teachers do not have any seminar-workshops on reflective teaching to develop themselves in their reflective teaching practices.

Keywords- reflective teaching, teaching practices, teachers' accounts, qualitative-quantitative study, triangulation.
\end{abstract}

\section{INTRODUCTION}

The Philippines is part of United Nations Educational, Scientific, and Cultural Organization (UNESCO). This organization structured National Education for All (EFA) to accomplish the predetermined goals. One of the goals is to improve all aspects in quality education and ensure excellence so that learning outcomes are achieved by all specifically literacy, numeracy and es sential life skills.

The National Achievement Test (NAT) of the Department of Education conducted annually measures the yearly academic level, strength and weaknesses of the knowledge learned by the students. NAT examinations aim to provide information on the pupils/students' level of achievement in Grades Six, Ten, and Twelve to guide policy makers, administrators, curriculum planners, supervisors, principals and teachers for the courses of action. It also identifies and analyzes varied achievement levels by region, division, school and other variables throughout the year. It determines the occurrence of improvement in basic education per individual schools in specified time frames. In order to gauge the EFA goal in achieving quality education, NAT is national standardized test aimed and used to determine the quality of education. This is the Philippines' measure of education quality. According to the Philippine EFA Review Report (2015)[1], the measure of education quality has been improving. As of school year 2012-2013, NAT's elementary level is 6.12 percentage away from target while NAT's secondary level is 23.59 percentage still missing from target. On the specified year, high school students had an overall MPS of 51.41 in all combined subjects. In English, the mean percentage score is 53.99; that is, almost 11 points lower than the expected MPS of 75 percent. However, the Philippines is still improving as compared to the previous eight-year NAT results but it is still far in attaining 75 , the target MPS.

Due to the country's unmet targets, Philippine EFA 2015 produces a National Plan of Action. In order to attain the sixth goal which is to achieve quality teaching, teachers have to promote practice of high quality teaching (Philippine EFA Review Report, 2015)[2].

In the DepEd Region 7, a Regional Memorandum No. 54 Series of 2016, dated January 25, 2016 was communicated to recognize the 2015 Harvest of Excellence Awards to Performing Schools Division Office. The Department of Education Region 7 held Harvest of Excellence Award Program last February 1, 2016. The activity aimed to recognize significant performance of Schools Divisions and School leaders. One of categories being recognized is the Level 8 Performance Based Bonus (PBB) in the secondary schools and divisions throughout the region. One of the qualifications to get a PBB is the MPS attained by the students in the school which may also reflect teachers' effectiveness. There were twelve (12) 
secondary schools recognized for the said category. Among the twelve (12), six (6) secondary schools are from Bohol, namely: Lila National High School (first in rank), Pres. Carlos P. Garcia Tech-Vocational School (second), Sikatuna National Agricultural High School (fourth), Handumon National High School (fifth), Cantubod National High School (seventh), and Hingotanan National High School (eighth).

If these schools got a PBB due to higher MPS, what do their teachers do attain such recognition? The question now is what do other teachers are doing that others are not doing? What others should be doing to attain higher MPS and achieve quality education? What makes a teacher effective?

Teaching is no easy job. Teachers are bound to be students for life. They attend classes for professional growth. It is a ticket to learn more of themselves and their students. While educating themselves, they also educate their students and make themselves liable of students' learning. If lessons are not earned and learned, they will tutor and do lecture again. Then, they need to assess students to address individual needs. They meet different personalities and coach them in different ways. They learn and unlearn things. They are always thinking what is best for their students. Their ups and downs in this profession will provide them with a meaningful experience before they are called a great teacher.

When the British Council organized a recent roundtable discussion with the its stakeholders, it admitted that the Philippines is doing fine with regards to English competency, but raised concerns on its competitive advantage for the country. That is why; the stakeholders decided that the country desires to elevate its efforts in refining the teaching and learning of English as a vital skill of Filipinos (Cabigon, 2016).[3] Teachers, the direct implementers of teaching and learning, are highly looked up to address this gap in cultivating the teaching and learning of English. They meet different situations inside the teaching and learning process where decisions are dependent to them; students look up to them with great respect. And this demands teachers to be a model of true value. Larrivee (2000)[4] mentioned that teachers need to realize that in their teaching profession they will be confronted continually with situations wherein they must make practical decisions. When an event or issue arises, the teachers need to realize that there is no prescribed checklist of how to respond (Mayes, 2001)[5]; they need to be able to determine an appropriate solution for that event or issue, which entails the process of reflective thinking.
When teachers are reflectively questioning their own teaching practices, they will become more reflective classroom teachers. Reflection is a skill teachers need to go deeper and apply by heart because they mold young minds. Different situations will test what makes a teacher. Teachers must have this skill and acquire the ability to be reflective thinkers. More than that, applying it is the ultimate goal of an effective teacher. Effective teachers are truly effective because they are reflective thinkers.

Reflection is a skill necessary to possess to address abrupt situations affecting teaching-learning process. Since there is no study conducted yet related to this topic in the province of Bohol, the researcher selected the in-service English teachers in the Department of Education (DepED). These teachers have a minimum of five-year experience, because reflection is a skill learned overtime, to crisscross if reflective teaching is really practiced.

The main purpose of this study was to determine the in-service English teachers' reflective teaching practices. For its output, it would hypothesize an emergent theory on reflective teaching.

\section{OBJECTIVES OF THE STUDY}

The main aim of this study is to hypothesize an emergent theory on reflective teaching of the English teachers who have at least five (5) years of teaching experience in the Department of Education in the province of Bohol. Specifically, this study determines the reflective practices of the in-service English teachers as viewed by the teachers themselves, their students and their principals, the significant difference on teachers' perceptions to reflective teaching practices as viewed by students and principals, the teachers' accounts on their own teaching practice, and the emergent theory on reflective teaching to be made based on the findings.

\section{MATERIALS AND METHODS}

The inductive approach on theory generation was used on this quantitative-qualitative research to determine the reflective teaching practices of in-service English teachers.

The locales of the study were the junior high schools in the Department of Education (DepED) Bohol Division. There are three congressional districts under the Bohol Division. A total of fifty-one (51) schools in the province of Bohol were covered in the study: the thirteen (13) schools from the first district, eighteen (18) schools from second district, and twenty (20) schools from third district. 
There were (3) three groups of respondents. The first group was the in-service junior high school English teachers who are connected in the Department of Education (DepEd). These teachers are teaching English subjects in the junior high schools in the province of Bohol. They have at least reached five (5) years of teaching experience in school year 2016-2017. Of the three (3) districts in the said province, there were thirty-two (32) teachers from the first district as respondents of the study. Second district had fifty (50) respondents while the third district had forty-two (42) English teachers. The total number of respondents was one hundred twenty-four (124). Purposive sampling was utilized.The second group of respondents was the principals of these English teachers. A total of fifty-one (51) principals were considered to be the respondents of the study: thirteen (13) for first district, eighteen (18) for second district, and twenty (20) for the third district. These principals rated the teaching practices of each teacher under their jurisdiction. There was a very high probability that a principal rated more than one teacher. The last group was the junior high school students of the in-service English teachers. Ten (10) students rated the teaching practices of one teacher. Since there were one hundred twenty-four (124) in-service English teachers, there was a total of one thousand two hundred forty $(1,240)$ students who participated in the study.

There were two (2) sets of instruments to get the reflective teaching practices of the in-service English teachers. The first instrument includes the adapted "Survey of Reflective Practice: A Tool for Assessing Development as a Reflective Practitioner for Facilitators and SelfAssessment developed by Barbara Larrivee (2008)[6]". This was answered by the in-service English teachers, their students and their principals. It is a rating scale: 5-often, 4usually, 3-sometimes, 2-rarely, and 1-never. It provides the reflective teaching practices categorized in four levels of reflection of the in-service English teachers. There are fourteen (14) items for pre-reflection, eleven (11) items for surface reflection, fourteen (14) items for pedagogical reflection, and fourteen (14) items for critical reflection. There are fifty-three (53) items in the questionnaire, and four (4) more items are blanked for additional inputs of the respondents. The last set of instrument is the interview schedule intended for in-service English teachers. This composes six (6) open-ended questions leading the inservice English teachers to ans wer the teachers' accounts they employed in their reflective teaching practices.

The researcher secured the permission and approval of the schools division superintendent of the division of Bohol. Having the approval, the researcher administered the questionnaires to the in-service English teachers, principals, and students of the English teachers. The interview was conducted after administering the questionnaires.

The data gathered were examined using Statistical Package for Social Studies (SPSS) for quantitative data. Weighted mean was utilized for the teaching practices and perceptions of the principals and students to the teaching practices of their teachers from the Rating Scale $(1-$ Never, 2 - Rarely, 3 - Sometimes, 4 - Usually, and 5 - Often) using the ranges 1:00-1.79, 1.80-2.59, 2.60-3.39, 3.40-4.19, and 4.20-5.00. For the qualitative data, NVivo 10 was used for the thematic analysis on the teachers' accounts on their teaching practices. From these analyses, the researcher hypothesized an emergent theory on reflective teaching.

\section{RESULTS AND DISCUSSION}

The in-service English teachers' reflective practices surfaced the way for the development of an emergent theory that illustrates how English teachers' account on their teaching practices as observed by their students and principals.

Theory Generation

According to Kerlinger (1986) in Lunenburg (2011)[7], a theory is a fixed interconnected concepts, definitions and propositions that grant a methodical observation of an occurrence by identifying relationships among variables for the purpose of elucidating, foreseeing and directing a phenomenon.

Theories generated in this study helps in preserving and in advancing knowledge in the field of English Language Teaching specifically English as a second language. To arrive at an emergent theory, which is tentative explanation of a phenomenon, the researcher used the theory generating steps of Fawcett and Downs (1994) in Bacus (2016)[8]. The four steps were undertaken.

Step 1. Identification and Classification of the Theory's Major Concept

With the use of the questionnaires and interview schedule, the English teachers' reflective teaching practices were recognized. Reflective teaching practices are behavioral actions performed by the English teachers using reflection. These actions are categorized into four levels of reflection, namely: pre-reflection, surface reflection, pedagogical reflection, and critical reflection. Teaching practices are observational actions performed by the English 
teachers. These actions are assessed by the principals and students of the said English teachers.

An analysis of the English teachers' account of their class room experiences revealed that teaching practices are behavioral actions performed by the English teachers inside their classes. These are identified in the teachers' account of their own teaching practices. These practices may not be following the reflective teaching. In this regard, there is a need for teachers' awareness to reflective teaching as this is an essential instrument to perform their duties as designed and intended for the topics assigned. The students and principals' perception of these English teachers will now play a role in making teachers aware also of their practices, reflective or not. This awareness will lead the English teachers to think and reflect of their teaching practices. It will also make teachers, later on, to reflect on their teaching practices. When teachers do reflection, they will be able to ascertain what has to, must be done and to be performed in their reflective teaching practices. They will be able to mirror their teaching practices, especially on the necessities it has to deal on students and classroom concerns. Teachers, with the help of their awareness and reflection to reflective teaching, can practice reflective teaching. In such event, reflective teaching will be practiced. The English teachers will be guided to reach the highest level of reflective teaching, critical reflection indicating to critically reflective teaching practices. Thus, this study designed the perception theory on reflective teaching practices of English teachers.

Step 2. Specifications of the Propositions Based on the Findings of the Study

Having drawn the concepts in this study, propositions were formulated. Propositions are declarative statements about a concept or the relationship between concepts. Fawcett and Downs (2000) in Bacus (2016)[9] opine that in theory generating research, the definition type of proposition is best. Definitional proposition is a statement that precisely defined the major concepts so that the implication of an idea can be illustrious from the implication of another idea.

In this study, the researcher, from the data and the observations made, deduced that:

1. Teaching practices are behavioral actions performed by the English teachers inside their classes.

2. Teachers' accounts are the materials or resources used to support the English teachers' reflection. These serve as platform for reflective teaching practices.
3. Teachers' awareness to reflective teaching is essential to perform their duties as designed and intended for the topics assigned. They will be aware of their teaching practices through the help of their students' and principals' perception of their own teaching practices.

4. When teachers do reflection, they will be able to ascertain what has to, must be done and to be performed in their reflective teaching practices. This skill will go a long way to help teachers improved themselves when it comes to reflective teaching.

5. Teachers, with the help of their awareness and reflection to reflective teaching, can practice reflective teaching and later on practice those practices. In such event, reflective teaching will be practiced. The English teachers will be guided to reach the highest level of reflective teaching, critical reflection indicating to critically reflective teaching practices. Thus, this study designed the perception theory on reflective teaching practices of English teachers.

Step 3. Hierarchical Ordering of the Propositions

The propositions stated in step 2 can be arranged based on the relationship of the major concepts. In this study, the propositions' ordering would be:

1. Teachers' awareness to reflective teaching is essential to perform their duties as designed and intended for the topics assigned. They will be aware of their teaching practices through the help of their students' and principals' perception of their own teaching practices.

2. Teaching practices are behavioral actions performed by the English teachers inside their classes.

3. Teachers' accounts are the materials or resources used to support the English teachers' reflection.

4. When teachers do reflection, they will be able to ascertain what has to, must be done and to be performed in their reflective teaching practices.

5. Teachers, with the help of their awareness and reflection to reflective teaching, can practice reflective teaching. The English teachers will be guided to reach the highest level of reflective teaching, critical reflection indicating to critically reflective teaching practices. Thus, this study designed the perception theory on reflective teaching practices of English teachers.

\section{Step 4. Construction of the Diagram}

Fawcett and Downs (2000) in Bacus (2016)[10] claimed that the final step in the theory formulation is the construction of a diagram of the theory. An illustration supports in defining by what means all concepts and propositions of the theory are carried together. It is the 
ultimate support to indulgent precisely what the theory pronounces and what it does not pronounce.

The Emergent Perception Theory on Reflective Teaching Practices

One of the objectives of this study was to develop a theory on ELT in the 21st century and onwards. Results of the study revealed an emergent theory: Perception Theory on Reflective Teaching.

The emergent perception theory on reflective teaching practices involves English teachers' awareness to reflective teaching through the help of students' and principals' perception, teaching practices inside their classes, teachers' accounts in teaching, teachers' reflection, teachers' practice to reflective teaching leading to be critically reflective teaching practices of English teachers. Thus, this study designed the perception theory on reflective teaching practices of English teachers. Figure 1 illustrates the relationships of the steps.

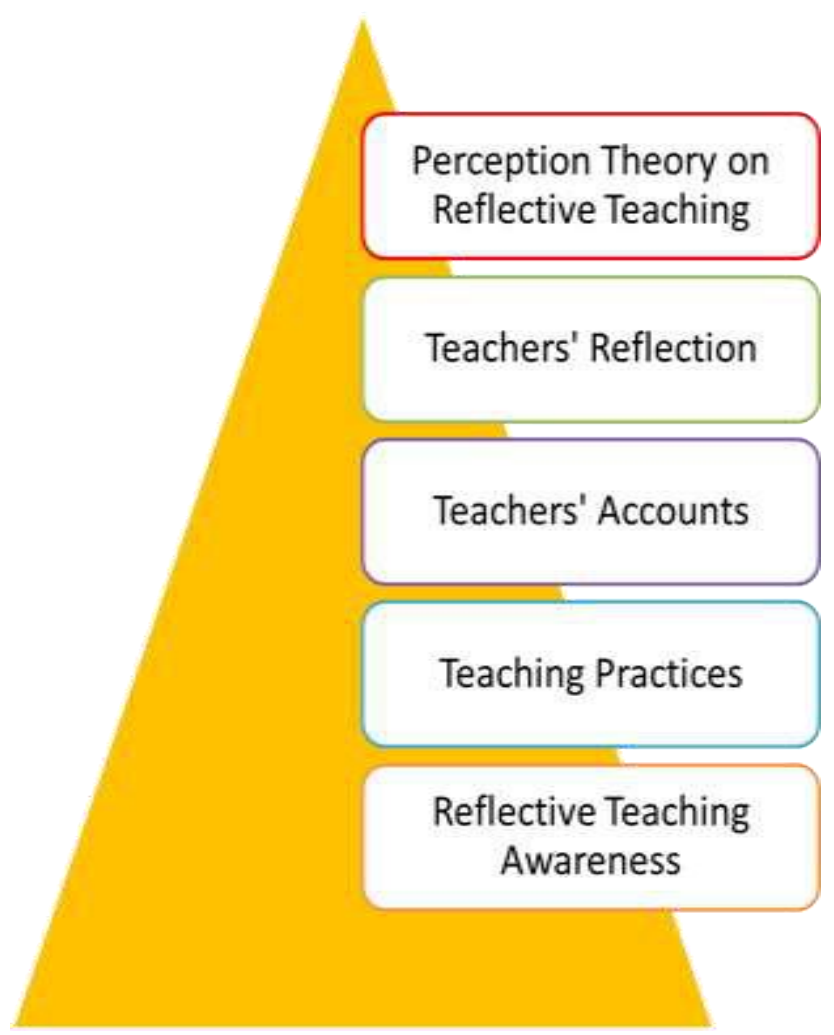

Fig.1: Perception Theory on Reflective Teaching

There is a need for teachers' awareness to reflective teaching as this is an essential instrument to perform their duties as designed and intended for the topics assigned. The students and principals' perception of these English teachers will now play a role in making teachers aware also of their practices, reflective or not. This awareness will lead the English teachers to think and reflect of their teaching practices. Teaching practices are behavioral actions performed by the English teachers inside their classes. These are identified in the teachers' account of their own teaching practices. These practices may not be following the reflective teaching. When teachers do reflection, they will be able to ascertain what has to, must be done and to be performed in their reflective teaching practices. They will be able to mirror their teaching practices, especially on the necessities it has to deal on students and classroom concerns. Teachers, with the help of their awareness and reflection to reflective teaching, can practice reflective teaching. In such event, reflective teaching will be practiced. With Larrivee's level of reflective teaching, the English teachers will be guided to reach the highest level of reflective teaching, critical reflection indicating to critically reflective teaching practices. Thus, this study designed the perception theory on reflective teaching practices of English teachers.

\section{CONCLUSIONS AND RECOMMENDATIONS}

Reflective teaching practices of the in-service English teachers do not reach the highest level of Larrivee's levels of reflection. This is reflected by the views of the students and principals of the in-service English teachers. Teachers' account on their teaching practices, as asked, offer different views from the in-service English teachers that the lack of idea on reflective teaching is ascertained. Thus, there is an emergence of the perception theory on reflective teaching.

Thus, the researcher recommends the following. Teacher education programs must have reflective teaching designs to prepare pre-service English teachers. In-service English teachers need to undergo self-reflection to know more of themselves as teachers and to base modifications of classroom procedures.The school administration may conduct in-service training on reflective teaching practices since these in-service English teachers do not have any seminar-workshops on reflective teaching.Action researches may be accomplished to provide empirical evidences on the improvement of the reflective teaching practices of these inservice English teachers.The following topics are recommended for future researches: Reflective Teaching Practices of Teacher Education Faculty, The Dynamics of Reflective Teaching in the Philippines, Train Reflective Teaching to English Teachers, Curriculum Design on Reflective Teaching in the Philippines, and Bridging the Gap in the Making of Critical Reflective Teachers 


\section{ACKNOWLEDGEMENT}

Commission on Higher Education K-12 Transition Program Scholarship- Dis sertation Grant

\section{REFERENCES}

[1] Philippine EFA Review Report (2015)

[2] Cabigon, M. (2016). State of english in the philippines: should we be concerned?

[3] Larrivee, B. (2000). Transforming teacher practice: Becoming the critically reflective teacher. Reflective Practice, 1(3), 293-307.

[4] Mayes, C. (2001). Deepening our reflectivity. The Teacher Educator, 36(4), 248-264.

[5] Larrivee, B. (2008). Development of a tool to assess teachers' levels of reflective practice. Reflective Practice, 9(3), 341-360.

[6] Lunenburg, F. C. (2011). Organizational cultureperformance relationships: Views of excellence and theory Z. In National Forum of Educational Administration and Supervision Journal (Vol. 29, No. 4, pp. 1-10).

[7] Bacus, R. (2016). Convergence and Divergence in ELT Credence, Practices, and Pedagogic Parameters: Adoption-Adaption Developmental Theory. Cebu Normal University

[8] Ibid 